\title{
Hepatic ischemia reperfusion injury: effect of moderate intensity exercise and oxytocin compared to L-arginine in a rat model
}

\author{
Amr H. ElKady ${ }^{1}$ D, Bataa M. Elkafoury', Dalia A. Saad*, Doaa M. Abd el-Wahed', Walaa Baher and \\ Mona A. Ahmed ${ }^{1}$
}

\begin{abstract}
Background: Hepatic ischemia reperfusion (IR) injury is considered as a main cause of liver damage and dysfunction. The L-arginine/nitric oxide pathway seems to be relevant during this process of IR. Although acute intense exercise challenges the liver with increased reactive oxygen species (ROS), regular training improves hepatic antioxidant status. Also, oxytocin (Oxy), besides its classical functions, it exhibits a potent antistress, anti-inflammatory, and antioxidant effects. This study was designed to evaluate the hepatic functional and structural changes induced by hepatic IR injury in rats and to probe the effect and potential mechanism of moderate intensity exercise training and/or Oxy, in comparison to a nitric oxide donor, L-arginine, against liver IR-induced damage.
\end{abstract}

Results: Compared to the sham-operated control group, the hepatic IR group displayed a significant increase in serum levels of ALT and AST, plasma levels of MDA and TNF-a, and significant decrease in plasma TAC and nitrite levels together with the worsening of liver histological picture. L-Arg, Oxy, moderate intensity exercise, and the combination of both Oxy and moderate intensity exercises ameliorated these deleterious effects that were evident by the significant decrease in serum levels of ALT and AST, significant elevation in TAC and nitrite, and significant decline in lipid peroxidation (MDA) and TNF-a, besides regression of histopathological score regarding hepatocyte necrosis, vacuolization, and nuclear pyknosis. Both the moderate intensity exercise-trained group and Oxy-treated group showed a significant decline in TNF-a and nitrite levels as compared to L-Arg-treated group. The Oxy-treated group showed statistical insignificant changes in serum levels of ALT, AST, and plasma levels of nitrite, MDA, TAC, and TNF-a as compared to moderate intensity exercise-trained group.

Conclusion: The combination of both moderate intensity exercise and Oxy displayed more pronounced hepatoprotection on comparison with L-Arg which could be attributed to their more prominent antioxidant and antiinflammatory effects but not due to their NO-enhancing effect.

Keywords: Liver, Ischemia reperfusion injury, L-arginine, Nitric oxide, Exercise, Oxytocin

\section{Background}

Hepatic ischemia reperfusion (IR) injury is considered as the main cause of liver damage and dysfunction or functional failure and contributes to a high morbidity and mortality $[1,2]$. Hepatic IR injury is commonly seen in

\footnotetext{
* Correspondence: Drdalia2009@med.asu.edu.eg

${ }^{1}$ Physiology Department, Faculty of Medicine, Ain Shams University, Cairo, Egypt

Full list of author information is available at the end of the article
}

hepatic surgery, such as in hepatectomy, liver transplantation, and resuscitation after shock [3, 4]. Also, abdominal trauma, myocardial ischemia, stroke, and hemorrhagic shock can cause insufficient liver blood flow, resulting in liver IR injury after reperfusion $[5,6]$.

The pathophysiology of hepatic IR injury is complex and multifactorial as it involves interaction with hepatocytes, liver sinusoidal and endothelial cells, Kupffer cells (KCs), and hepatic stellate cells. Also, it results in 
infiltration of inflammatory cells, activation of platelets, generation of reactive oxygen species (ROS), and reactive nitrogen species due to ischemia as well as reperfusion, increased levels of adhesion molecules, and release of cytokines and chemokines $[7,8]$.

During hepatic IR, the role of nitric oxide (NO) is ambiguous, because it may protect from the lesion owing to its vasodilator, antiplatelet, and ROS scavenging effect, or it may be a deleterious agent due to its interaction with superoxide radicals, forming peroxynitrite radicals $[9,10]$.

Exercise has been considered an important therapeutic tool in preventing and treating many diseases including obesity, non-alcoholic fatty liver disease, insulin resistance, type 2 diabetes, metabolic cardiovascular, and gastrointestinal disorders [11-13]. On the other hand, exercise may represent a physical stress that result in transient disruption of homeostasis [14]. The liver is considered the remarkably important organ during exercise outcomes due to its contribution in the modulation of ROS and inflammatory mediators [15]. Although acute intense exercise was found to challenge the liver with increased ROS and inflammation onset, regular exercise was found to induce hepatic antioxidant and antiinflammatory improvements [16].

Oxytocin (Oxy), the hormone released from the posterior pituitary, besides its classical functions, was reported to exhibit a wide spectrum of central and peripheral activities [17]. Oxy has been shown to stimulate social behaviors and exert a potent anti-stress effect by reducing the activity in the hypothalamic-pituitary adrenocortical axis and sympathetic nervous system, and possess antioxidant and anti-inflammatory effects [18, 19]. Hekimoglu et al. [20] observed that Oxy protect against renal IR-induced remote liver injury by increasing NO synthase activity and releasing $\mathrm{NO}$ from vascular endothelium, suppression of inflammation, and regulation of oxidant-antioxidant status.

This study was carried out to investigate hepatic functional and structural changes induced by hepatic IR and to evaluate the effect and potential mechanisms of moderate intensity exercise training and Oxy, together or separately, in comparison to, a NO donor, L-arginine (LArg) in protecting the liver function from the damage induced by hepatic IR.

\section{Methods}

This study was carried out on 60 adult male albino rats, initially weighing $250-300 \mathrm{~g}$. Rats were purchased from an animal farm in Helwan and were housed in the Faculty of Medicine, Ain Shams Research Institute (MASR I), under standard conditions of boarding at room temperature $22-25^{\circ} \mathrm{C}, 12$-h light/dark cycle with free access to food and water. Regular meals were introduced daily at $8 \mathrm{am}$. Rats were fed standard rat diet. Rats were kept for 7 days before the experimental procedures for acclimatization. Animals included in the study were adult males after successful induction of the designated experiment and no animals were excluded.

Animal experiments were conducted in accordance to the Guide for Care and Use of Laboratory Animals, and the study protocol was approved by the Research Ethical Committee of Faculty of Medicine, Ain Shams University (FMASU, MD 100/2018).

\section{Experimental animals}

Rats were randomly allocated into the following six groups:

\section{Group I: Sham-operated control (sham group) ( $n=10)$}

In the first 3 weeks, rats were kept undisturbed in their cages. In the fourth week, rats received L-Arg solvent daily, at $9 \mathrm{am}$, by oral gavage. At the end of the 4 weeks, rats were subjected to the same surgical procedures as the hepatic IR group without portal triad clamping.

\section{Group II: Hepatic ischemia-reperfusion group (hepatic IR group) ( $n=10)$}

In the first 3 weeks, rats were kept undisturbed in their cages. In the fourth week, rats received L-Arg solvent daily, at 9 am, by oral gavage. At the end of the fourth week, rats underwent hepatic IR procedure $(30 \mathrm{~min}$ of partial hepatic ischemia (70\%) followed by $2 \mathrm{~h}$ of reperfusion) [21].

\section{Group III: L-arginine-treated hepatic ischemia-reperfusion group (L-Arg + IR group) $(n=10)$}

In the first 3 weeks, rats were kept undisturbed in their cages. In the fourth week, rats received L-Arg daily, at 9 $\mathrm{am}$, by oral gavage in a dose of $100 \mathrm{mg} / \mathrm{kg}$ (7 days) [22].

\section{Group IV: Exercise-trained hepatic ischemia-reperfusion group (Ex + IR group) $(n=10)$}

Rats in this group were studied after 4 weeks of exposure to swim exercise $2 \mathrm{~h}$ daily (from 10 am to $12 \mathrm{pm}$ ) and 6 days/week [23]. In the fourth week, rats received distilled water as in sham group. At the end of the fourth week, rats underwent hepatic IR procedure.

\section{Group V: Oxytocin-treated hepatic ischemia-reperfusion group (Oxy + IR group) $(n=10)$}

In the first 3 weeks, rats were kept undisturbed in their cages. In the fourth week, rats received distilled water as in the sham group together with Oxy, daily at 9:30 am, by subcutaneous (S.C.) injection in a dose of $3.6 \mu \mathrm{g} / 100$ g BW [24]. At the end of the fourth week, rats underwent hepatic IR procedure. 


\section{Group VI: Exercise-trained and oxytocin-treated hepatic} ischemia-reperfusion group ( $E x+O x y+I R$ group) $(n=10)$

Rats in this group were studied after 4 weeks of exposure to swim exercise as in Ex + IR group. In the fourth week, rats received daily distilled water and S.C. Oxy as in Oxy + IR group. At the end of the fourth week, rats underwent hepatic IR procedure.

\section{Experimental procedures} L-arginine treatment

L-Arg was supplied as powder by the Qualikems Fine Chemicals (New Delhi, India). A $100 \mathrm{mg}$ of L-Arg was dissolved in 2-ml distilled water to make the final concentration of $50 \mathrm{mg} / \mathrm{ml}$. At the beginning of fourth week of the study, rats received L-Arg, daily at 9 am by oral gavage in a dose of $100 \mathrm{mg} / \mathrm{kg}$ for 7 days [22].

\section{Exercise Swim Training Program}

At the beginning of the program, the aquatically naive rats were given the chance to stay in the water bath for $30 \mathrm{~min}$ in order to become familiar with water. This period was progressively increased everyday by $30 \mathrm{~min}$ till it reached $2 \mathrm{~h}$ per day, and this duration was maintained throughout the exercise period [25].

The dimensions of the swimming tank used were 70 $\mathrm{cm}$ in depth, $100 \mathrm{~cm}$ in length, and $70 \mathrm{~cm}$ in width. The tank was filled with water to a depth of $50 \mathrm{~cm}$. Swimming water temperature was maintained at a thermoneutral temperature of $31 \pm 1^{\circ} \mathrm{C}$. The tank is equipped with a fan with strong motor (1425 revolutions per minute) that stir strong water currents. This equipment acts as a helping force to the rats to swim actively all the time and ensure uniformity of temperature. After each swimming session, the water was emptied from the tank and the tank was thoroughly cleaned.

The protocol of swimming consisted of one session of $2 \mathrm{~h}$ (from 10 am to $12 \mathrm{pm}$ ), 6 days/week for 4 weeks, which is considered a moderate intensity aerobic exercise [23].

\section{Oxytocin treatment}

Oxy was in the form of ampoules (10 IU/ml) supplied by the Novartis Pharmaceuticals (Switzerland). At the beginning of fourth week of the study, Oxy was administered daily at 9:30 am, by S.C. injection in a dose of 3.6 $\mu \mathrm{g} / 100 \mathrm{~g}$ BW for 7 days [24].

\section{Hepatic ischemia-reperfusion procedure}

Hepatic IR in the present study was a model of partial hepatic ischemia (70\% of liver mass) performed according to the method described by Shibamoto et al. [21]. The overnight fasted rats were weighed and anesthetized by intraperitoneal (i.p.) injection of ketamine (EPICO) in a dose of $50 \mathrm{mg} / \mathrm{kg}$ and xylazine $\mathrm{HCl}$ (ADWIA) in a dose of $10 \mathrm{mg} / \mathrm{kg}$ [26].

A midline longitudinal laparotomy was performed, followed by section of the falciform ligament. Then, by delicate digital maneuvers, the median hepatic lobe was pushed upwards in cranial direction to allow the exposure of the hepatic pedicle. Partial hepatic ischemia was induced by clamping the portal vein, hepatic artery, and bile duct (portal triad) supplying the median and left lobes with an atraumatic vascular clamp. In this method, the blood supply to the right and caudate lobes remained uninterrupted, attenuating intestinal congestion through portal flow bypass. Successful induction of the hepatic IR procedure was determined by visually comparing the ischemic lobes of liver (the median and left lobes) which turned pale denoting establishment of ischemia compared to non-ischemic lobes (right and caudate lobes), and also, successful reperfusion was observed by turning the color of ischemic lobes back to their pre-ischemic period and the non-ischemic lobes.

The abdomen was humidified with a saline solution in order to avoid fluid loss through evaporation, and the muscular layer was approximated with single stitches. After $30 \mathrm{~min}$ of ischemia, reperfusion was initiated by removing the clamp, and the abdomen was closed in a single layer. The animals were, then, allowed to recover. The reperfusion was allowed for $2 \mathrm{~h}$.

The time of each procedure done was fixed throughout the study. All other groups-sham group, hepatic IR group, Ex + IR group, Oxy + IR group, and Ex + Oxy + IR group, also, received distilled water (L-Arg solvent) orally by gavage at 9 am for the same duration given to L-Arg + IR group in order to exclude the effect of the solvent and the maneuver of gavage. In addition, at the end of the study, the sham-operated control group was subjected to the same surgical steps of hepatic IR procedure without clamping of the portal triad, to exclude the effect of anesthesia, surgical incision, and the maneuver of hepatic pedicle exposure on the results obtained from rats that underwent hepatic IR.

Animals were not exposed to unnecessary pain or stress and animal manipulation was performed with maximal care and hygiene.

At the end of the reperfusion, rats were anaesthetized by i.p. injection of pentobarbital sodium (El-Gomhoreya Co., Egypt), in a dose of $40 \mathrm{mg} / \mathrm{kg}$ [27].

Then, a midline abdominal incision was made, and the abdominal aorta was exposed and cannulated. The blood was collected from the aorta into two tubes, a heparinized tube and serum clot activator tube with gel and then separated to plasma or serum and was stored at $-80^{\circ} \mathrm{C}$ for later determination of biochemical assays.

After blood collection, animals were euthanized by intraperitoneal injection of overdose of pentobarbital 
sodium (El-Gomhoreya Co., Egypt), in a dose of $200 \mathrm{mg} /$ $\mathrm{kg}$.

Then, the liver was carefully dissected, and the left lobe of the liver was fixed in $10 \%$ buffered formalin solution for subsequent histopathological examination. Animal remains disposal occurred by incineration.

\section{Biochemical analysis}

- Determination of serum levels of alanine transferase (ALT) and aspartate transferase (AST) according to Henry [28] and Tietz [29], by the kinetic method optimized in accordance with I.F.C.C [30]., using BioMed-GPT kits supplied by Egy-Chem for Lab Technology, Egypt.

- Determination of the plasma level of nitrite according to Montgomery and Dymock [31], using the colorimetric kit supplied by Bio-diagnostic, Egypt.

- Determination of plasma level of malondialdehyde (MDA) according to Satoh [32] and Ohkawa et al. [33] using the colorimetric kit supplied by Biodiagnostic, Egypt.

- Determination of the plasma level of total antioxidant capacity (TAC) according to Koracevic et al. [34], using colorimetric kit supplied by Biodiagnostic, Egypt.

- Determination of the plasma level of tumor necrosis factor-alpha (TNF- $\alpha$ ) by an enzyme immunoassay (ELISA) technique (Stat Fax 2100, Awareness Technology Inc, USA), using Rat TNF- $\alpha$ ELISA kits supplied by RayBio ${ }^{\circ}$ tech, Inc., USA (Catalog: ELR-

TNFa) according to the manufacturer instructions.

\section{Histological examination of the liver tissue}

The dissected specimens from the left lobe of the liver were fixed with $10 \%$ formalin solution immediately after removal (for at least 1 week) and were subjected to dehydration in ascending grades of alcohol, cleared in xylol, impregnated in pure soft paraffin, and embedded in hard paraffin [35]. Sections (8 $\mu \mathrm{m})$ were cut and stained with hematoxylin and eosin (H\&E). For microscopic examination, a microscope (Leica, DM2500) was used, and the images were taken at the Histology and Cell Biology Department, Faculty of Medicine, Ain Shams University, using a Canon EOS 1100D Digital SLR camera at 10 (ocular) $\times 40$ (object lens) magnification. The liver histopathological changes were scored based on $\mathrm{Su}$ zuki et al. [36].

\section{Statistical analysis}

All statistical data, statistical significance, and correlations were performed by using the Statistical Program for Social Science (SPSS) statistical package (SPSS Inc.) version 20.0. One-way ANOVA was used to test for differences among the studied groups followed by LSD (least significant difference) to find inter-groupal significance. Results were expressed as mean and \pm standard error of the mean and considered significant at a level $\mathrm{P}<0.05$.

\section{Results}

Changes in serum levels of alanine transferase (ALT) and aspartate transferase (AST) and plasma level of nitrite (Table 1 and Fig. 1)

As compared to the sham group, the hepatic IR group resulted in a significant increase in the serum levels of ALT and AST. L-Arg + IR, Ex + IR, and Oxy + IR groups showed a significant decrease in the serum levels of ALT and AST compared to the hepatic IR group, but were significantly increased compared to sham group. LArg + IR, Ex + IR, and Oxy + IR groups exhibited statistically insignificant changes in the serum levels of ALT and AST when compared to each other.

Combined Ex + Oxy + IR group showed a significant reduction in serum levels of ALT and AST as compared to hepatic IR, L-Arg + IR, and Ex + IR groups. However, when compared to the sham group, the ALT level was significantly elevated, but the AST level was insignificantly changed.

As compared to the sham group, the hepatic IR group showed a significant decrease in the plasma level of nitrite. All treated groups-L-Arg+ IR, Ex+ IR, Oxy + IR, and combined Ex + Oxy + IR groups, showed a significant increase in the plasma level of nitrite as compared to the hepatic IR group. In L-Arg + IR group, the plasma level of nitrite showed a insignificant changes as compared to sham group. Both Oxy + IR and combined Ex + Oxy + IR groups showed statistically insignificant changes in the plasma level of nitrite as compared to the $\mathrm{Ex}+\mathrm{IR}$ group, whereas in Ex + IR, Oxy + IR, and combined Ex + Oxy + IR groups, the nitrite level was significantly reduced compared to both the L-Arg + IR and sham groups.

\section{Changes in plasma levels of malondialdehyde (MDA), total antioxidant capacity (TAC), and tumor necrosis factor-alpha (TNF-a) (Table 2 and Fig. 2)}

As compared to the sham group, the hepatic IR group showed a significant increase in the plasma levels of MDA and TNF- $\alpha$, but significant decrease in the plasma level of TAC.

Compared to the IR group, all the treated groups- $\mathrm{L}-$ Arg + IR, Ex + IR, Oxy + IR, and combined Ex + Oxy + IR groups, the plasma levels of MDA and TNF- $\alpha$ were significantly decreased, whereas the plasma level of TAC was significantly increased. 
Table 1 Changes in the serum levels of alanine transferase (ALT) and aspartate transferase (AST), and the plasma level of nitrite in the different studied groups

\begin{tabular}{|c|c|c|c|}
\hline Parameters groups & $\begin{array}{l}\text { ALT } \\
\mathrm{U} / \mathrm{ml}\end{array}$ & $\begin{array}{l}\text { AST } \\
\mathrm{U} / \mathrm{ml}\end{array}$ & $\begin{array}{l}\text { Nitrite } \\
\mu \mathrm{mol} / \mathrm{g}\end{array}$ \\
\hline Sham-operated control & $15.30 \pm 0.955$ & $21.30 \pm 1.484$ & $10.94 \pm 0.596$ \\
\hline Hepatic ischemia-reperfusion & $51.70 \pm 3.134^{\mathrm{a}}$ & $62.70 \pm 4.475^{a}$ & $2.879 \pm 0.477^{\mathrm{a}}$ \\
\hline L-arginine-treated hepatic ischemia-reperfusion & $28.00 \pm 1.308^{\mathbf{a}, \mathbf{b}}$ & $32.30 \pm 1.274^{\mathbf{a}, \mathbf{b}}$ & $11.32 \pm 0.886^{\mathbf{b}}$ \\
\hline Exercise-trained hepatic ischemia reperfusion & $26.70 \pm 1.023^{\mathbf{a}, \mathbf{b}}$ & $31.0 \pm 2.066^{\mathbf{a}, \mathbf{b}}$ & $6.240 \pm 0.644^{\text {a, b, } \mathbf{c}}$ \\
\hline Oxytocin-treated hepatic ischemia-reperfusion & $25.00 \pm 1.528^{\mathbf{a}, \mathbf{b}}$ & $31.30 \pm 1.521^{\mathbf{a}, \mathbf{b}}$ & $5.240 \pm 0.578^{\mathbf{a}, \mathbf{b}, \mathbf{c}}$ \\
\hline Exercise-trained and oxytocin-treated hepatic ischemia-reperfusion & $20.50 \pm 1.500^{\mathbf{a}, \mathbf{b}, \mathbf{c}, \mathbf{d}}$ & $22.20 \pm 1.705^{\mathbf{b}, \mathbf{c}, \mathbf{d}}$ & $7.790 \pm 0.484^{a, b, c}$ \\
\hline
\end{tabular}

Results are expressed as mean \pm SEM and calculated by LSD at $P<0.05$

${ }^{\text {a }}$ Significance from the sham-operated control group

${ }^{\mathrm{b}}$ Significance from the hepatic ischemia-reperfusion group

'Significance from the L-arginine hepatic ischemia-reperfusion group

${ }^{d}$ Significance from the exercise-trained hepatic ischemia-reperfusion group

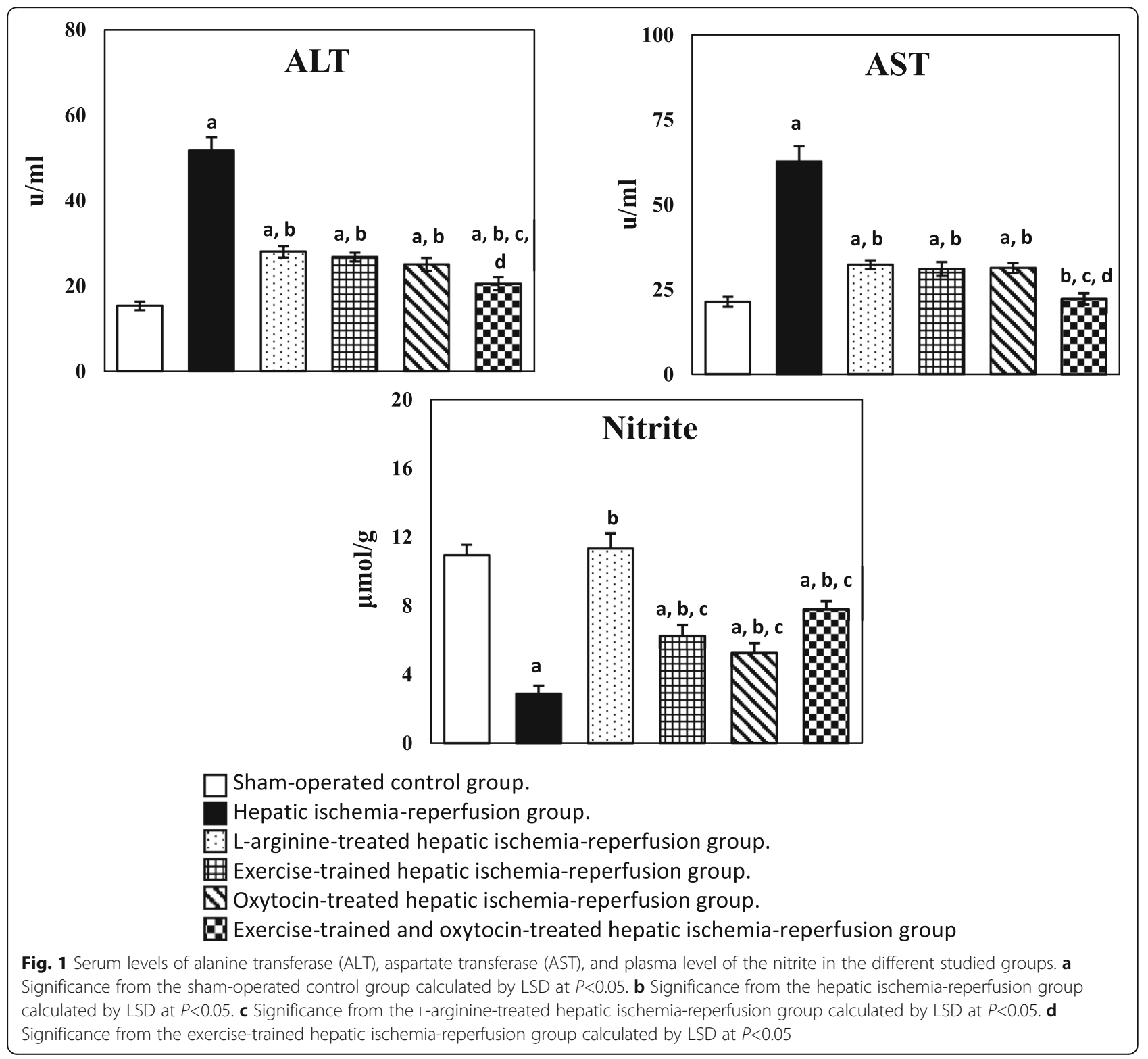


Table 2 Changes in the plasma levels of malondialdehyde (MDA), total antioxidant capacity (TAC), and tumor necrosis factor-alpha (TNF-a) in the different studied groups

\begin{tabular}{|c|c|c|c|}
\hline Parameters groups & $\begin{array}{l}\mathrm{MDA} \\
\mathrm{nmol} / \mathrm{g}\end{array}$ & $\begin{array}{l}\text { TAC } \\
\mathrm{mM} / \mathrm{L}\end{array}$ & $\begin{array}{l}\text { TNF-a } \\
\mathrm{pg} / \mathrm{ml}\end{array}$ \\
\hline Sham-operated control & $25.94 \pm 3.237$ & $80.48 \pm 5.427$ & $56.43 \pm 3.662$ \\
\hline Hepatic ischemia-reperfusion & $110.6 \pm 5.978^{a}$ & $28.38 \pm 2.584^{a}$ & $145.2 \pm 4.727^{\mathbf{a}}$ \\
\hline L-arginine-treated hepatic ischemia-reperfusion & $67.70 \pm 5.666^{\mathbf{a}, \mathbf{b}}$ & $66.54 \pm 3.784^{a, b}$ & $96.24 \pm 2.282^{\mathbf{a}, \mathbf{b}}$ \\
\hline Exercise-trained hepatic ischemia reperfusion & $56.08 \pm 4.002^{\mathbf{a}, \mathbf{b}}$ & $70.16 \pm 3.938^{\mathbf{b}}$ & $85.52 \pm 3.995$ a, b, c \\
\hline Oxytocin-treated hepatic ischemia-reperfusion & $63.00 \pm 4.567^{\mathrm{a}, \mathrm{b}}$ & $65.30 \pm 3.711^{\mathbf{a}, \mathbf{b}}$ & $77.51 \pm 2.721^{a, b, c}$ \\
\hline Exercise-trained and oxytocin-treated hepatic ischemia-reperfusion & $40.96 \pm 4.334^{a, b, c, d}$ & $76.77 \pm 3.853^{\mathbf{b}}$ & $73.68 \pm 3.612^{a, b, c, d}$ \\
\hline
\end{tabular}

Results are expressed as mean \pm SEM and calculated by LSD at $\mathrm{P}<0.05$

a Significance from the sham-operated control group

${ }^{\mathrm{b}}$ Significance from the hepatic ischemia-reperfusion group

'Significance from the L-arginine hepatic ischemia-reperfusion group

${ }^{\mathrm{d}}$ Significance from the exercise-trained hepatic ischemia-reperfusion group

However, in all studied treated groups, the plasma levels of MDA and TNF- $\alpha$ were still significantly higher compared to the sham group, whereas the plasma level of TAC was significantly decreased as compared to the sham group. Moreover, all the treated groups showed significantly lower plasma level of TAC except for Ex + IR and combined Ex + Oxy + IR groups which showed non-significant changes in TAC level.

Compared to the L-Arg + IR group, Ex + IR, and Oxy + IR groups showed a significant reduction in the plasma level of TNF- $\alpha$ with insignificant changes in the plasma levels of MDA and TAC, while the combined Ex + Oxy + IR group showed a significant reduction in the plasma levels of both MDA and TNF- $\alpha$ with nonsignificant change in the plasma level of TAC.

Compared to the Ex + IR group, the Oxy + IR group did not show any significant changes in the plasma levels of MDA, TAC, and TNF- $\alpha$, while the combination of exercise and Oxy showed significantly lower plasma levels of MDA and TNF- $\alpha$, but the plasma level of TAC exhibited an insignificant change.

\section{Correlations between liver function parameters and other parameters (Fig. 3)}

In correlation studies, the results were obtained from pooling of the different studied groups.

The serum levels of ALT and AST showed significant positive correlations with the plasma levels of MDA and TNF- $\alpha$, but significant negative correlations with the plasma levels of TAC and nitrite.

\section{Histopathological studies}

\section{Microscopic examination of the liver (Figs. 4 and 5)}

The photomicrography of liver tissue of the shamoperated control group (Fig. 2a) showed that the liver was formed of acidophilic polyhedral hepatocytes having large central vesicular nuclei. The hepatocytes are arranged in irregular branching and anastomosing plates around a central vein $(\mathrm{CV})$. The plates of hepatocytes are separated from each other by blood sinusoids $(\uparrow)$.

The photomicrography of the liver tissue of the hepatic IR group was shown in Fig. 4b, c. Figure $4 \mathrm{~b}$ showed a wide area of hepatocyte vacuolization $(\boldsymbol{\Delta})$, congestion of blood sinusoids $(\uparrow)$, and darkly stained pyknotic nuclei $(\mathrm{P})$ in most of the hepatocytes. Figure 4 c showed wide area of focal hepatic necrosis (thick arrow) in which a number of adjacent hepatocytes are lost and replaced by inflammatory cells.

Photomicrography of the liver tissue of L-Arg group (Fig. 5a) showed dilatation and congestion of blood sinusoids $(\boldsymbol{\Delta})$ in between hepatocytic cords. Some sporadic hepatocytes show condensed pyknotic nuclei $(\uparrow)$, whereas a small focal area of hepatocytic necrosis (thick arrow) is detected.

The photomicrography of the liver tissue of the Ex + IR group (Fig. $5 \mathrm{~b}$ ) showed dilatation and congestion of the blood sinusoids separating hepatocytes plates $(\boldsymbol{\Lambda})$. Focal areas of hepatocytes necrosis (thick arrow) in which the hepatocytes are replaced by inflammatory cells. Some hepatocytes show cytoplasmic vacuolization $(\uparrow)$.

Photomicrography of the liver tissue of the Oxy group (Fig. 5c) showed the focal area of hepatic necrosis (thick arrow) in which the hepatocytes are replaced by inflammatory cells. Some hepatocytes show vacuolation of their cytoplasm $(\mathrm{V})$.

Photomicrography of the liver tissue of the combined Ex + Oxy group (Fig. 5d) showed a congestion of blood sinusoids $(\mathbf{\Delta})$. A small focal area of hepatic necrosis (thick arrow) is detected where the hepatocytes are replaced by inflammatory cells.

\section{Histopathological grading of the liver (Table 3)}

As shown in Table 3, the histopathological grading for liver changes included three parameters: congestion, vacuolization, and necrosis. For all parameters, the 

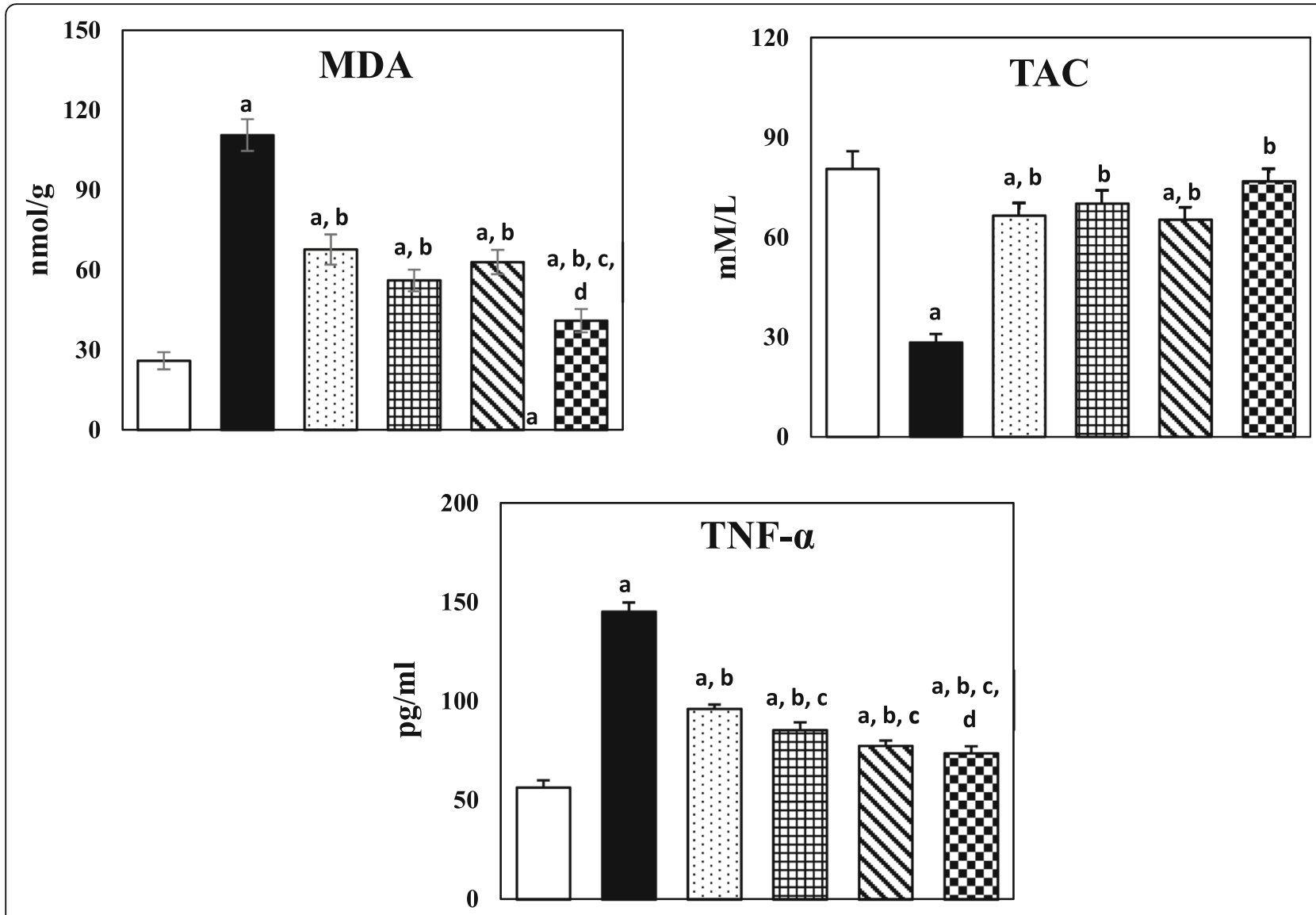

$\square$ Sham-operated control group.

Hepatic ischemia-reperfusion group.

L-arginine-treated hepatic ischemia-reperfusion group.

Exercise-trained hepatic ischemia-reperfusion group.

\$oxytocin-treated hepatic ischemia-reperfusion group.

Exercise-trained and oxytocin-treated hepatic ischemia-reperfusion group

Fig. 2 Plasma levels of malondialdehyde (MDA), total antioxidant capacity (TAC), and tumor necrosis factor-alpha (TNF-a) in the different studied groups. a Significance from the sham-operated control group calculated by LSD at $P<0.05$. $\mathbf{b}$ The significance from the hepatic ischemiareperfusion group calculated by $L S D$ at $P<0.05$. c The significance from the L-arginine-treated hepatic ischemia-reperfusion group calculated by LSD at $P<0.05$. d The significance from the exercise-trained hepatic ischemia-reperfusion group calculated by LSD at $P<0.05$

hepatic IR group was the most affected and was graded for the highest scores in all parameters.

As regards congestion, the hepatic IR group was the most affected group followed by the L-Arg group and Oxy group as $65 \%, 55 \%$, and $50 \%$, respectively, of examined fields showed congestion in zones 2 and 3 of most lobules (score 3). On the other hand, the combined Ex + Oxy group scored 2 as $55 \%$ of the examined fields showed zone 3 sinusoidal congestion in some lobules. The least affected group by congestion was the Ex group, which scored 1 as $60 \%$ of the examined fields revealed scattered sinusoidal congestion.
Regarding hepatocellular vacuolization, the hepatic IR group was the most affected group in which $55 \%$ of the examined fields showed prominent clusters of hepatocellular vacuolization in most lobules (score 3). On the other hand, L-Arg, Ex, Oxy, and Ex + Oxy groups were all scored 1 but with variable percentages as $50 \%, 60 \%$, $50 \%$, and $60 \%$, respectively, of the examined fields showed scattered cell vacuolization in most lobules or prominent cluster in one lobule.

Regarding the necrosis of the hepatocellular tissue, the hepatic IR group was the most affected group and the only group that scored 2 , as $55 \%$ of the examined fields 

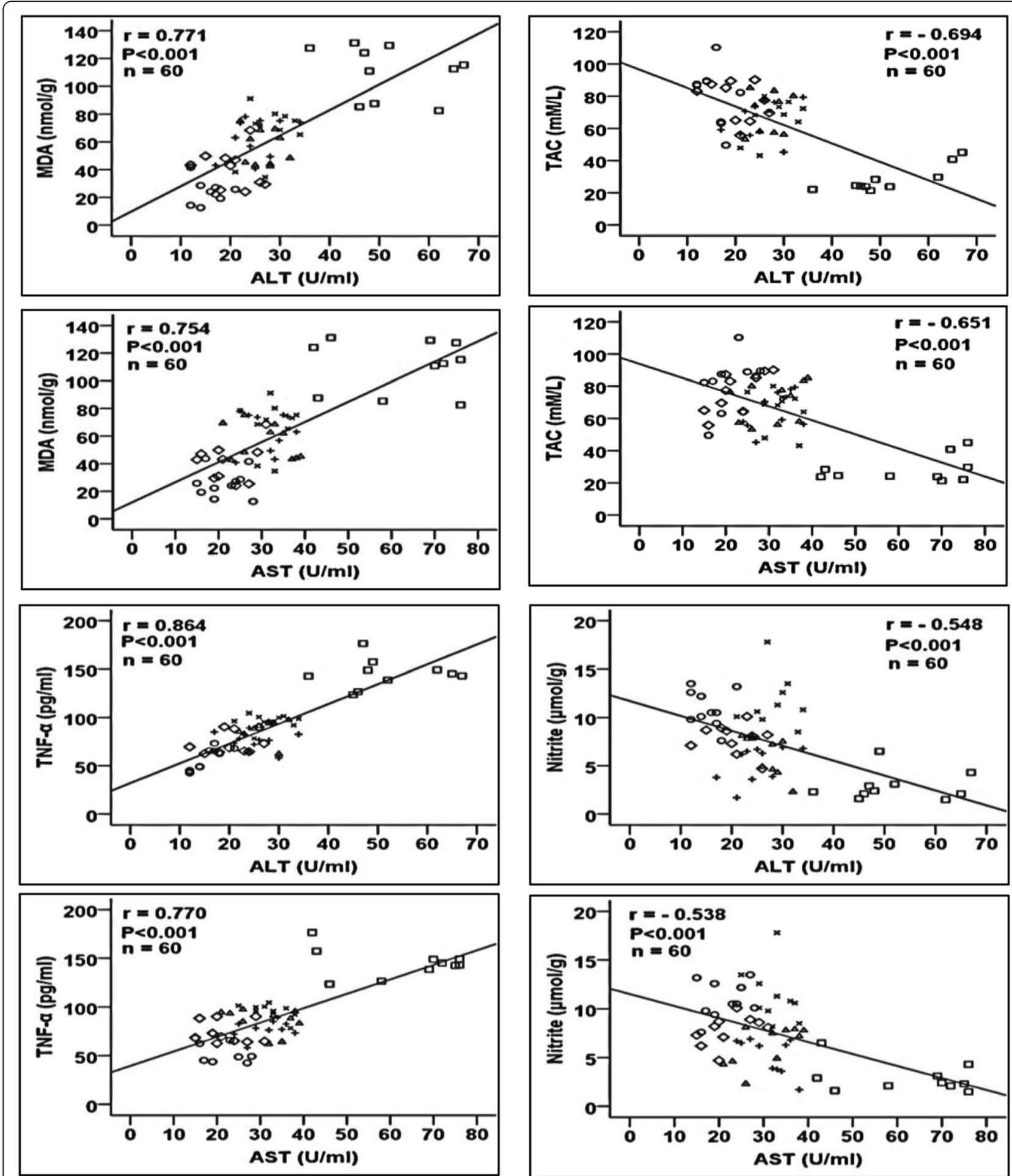

Fig. 3 Correlations between the serum levels of alanine transferase (ALT), aspartate transferase (AST), and plasma levels of malondialdehyde (MDA), total antioxidant capacity (TAC), tumor necrosis factor-alpha (TNF-a), and nitrite in the different studied groups. o Sham-operated control group. $\square$ Hepatic ischemia-reperfusion group. x L-arginine-treated hepatic ischemia-reperfusion group. $\Delta$ Exercise-trained hepatic ischemiareperfusion group. + Oxytocin-treated hepatic ischemia-reperfusion group. $\diamond$ Exercise-trained and oxytocin-treated hepatic 

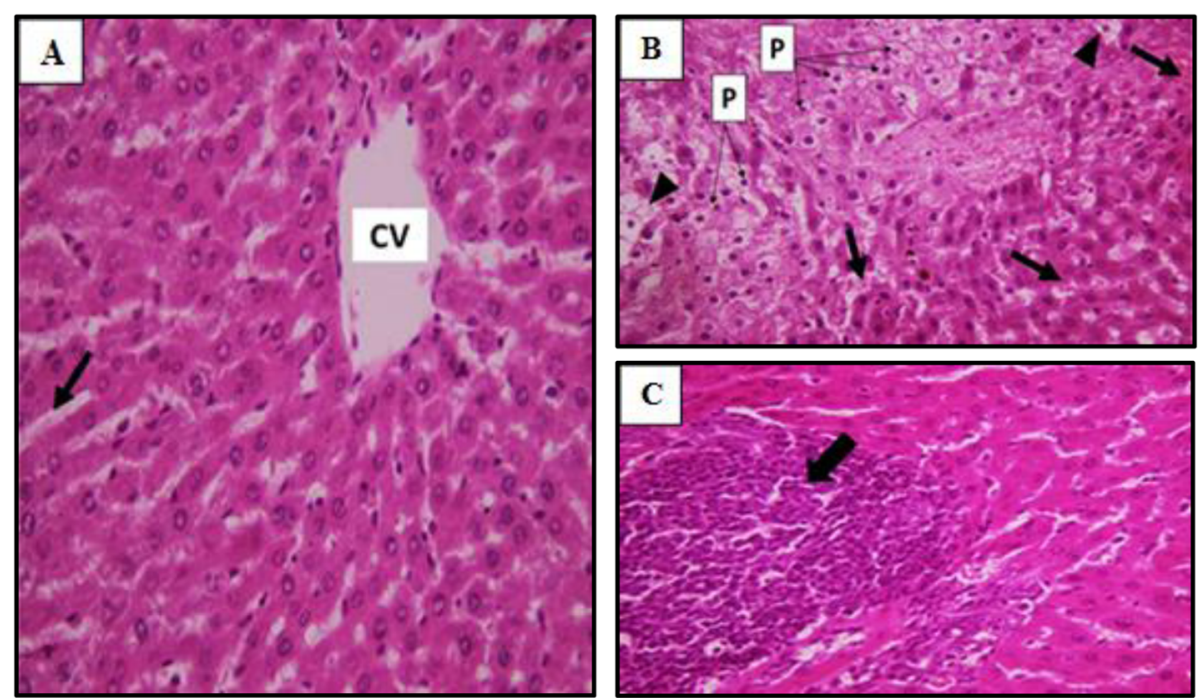

Fig. 4 Photomicrograph of liver tissue sections: a Sham-operated control group and b, c hepatic ischemia reperfusion group). (H\&E X400)

showed less than $30 \%$ necrosis. On the other hand, LArg, Ex, Oxy, and Ex + Oxy groups, scored 1 as 45\%, $50 \%, 55 \%$, and $55 \%$, respectively, of the examined fields in each group showed a single-cell necrosis in most lobules.

\section{Discussion}

In this work, hepatic ischemia was successfully induced by $70 \%$ occlusion for $30 \mathrm{~min}$ followed by $2 \mathrm{~h}$ reperfusion. Hepatic IR resulted in hepatic injury as proved by increased level of liver enzymes. Hepatic IR causes the disruption of the membrane stability of hepatocytes due to necrosis, cellular damage, and structural changes with release of large quantities of liver enzymes [37-39].

Moreover, a histopathological study showed a corrupted hepatic architecture in the form of hepatocyte vacuolization and necrosis, nuclear pyknosis, lymphocytic infiltration, and congestion of blood sinusoids. These findings agree with the results of previous studies by Peralta et al. [40], Serracino-Inglatt et al. [41], and Crockett et al. [42].
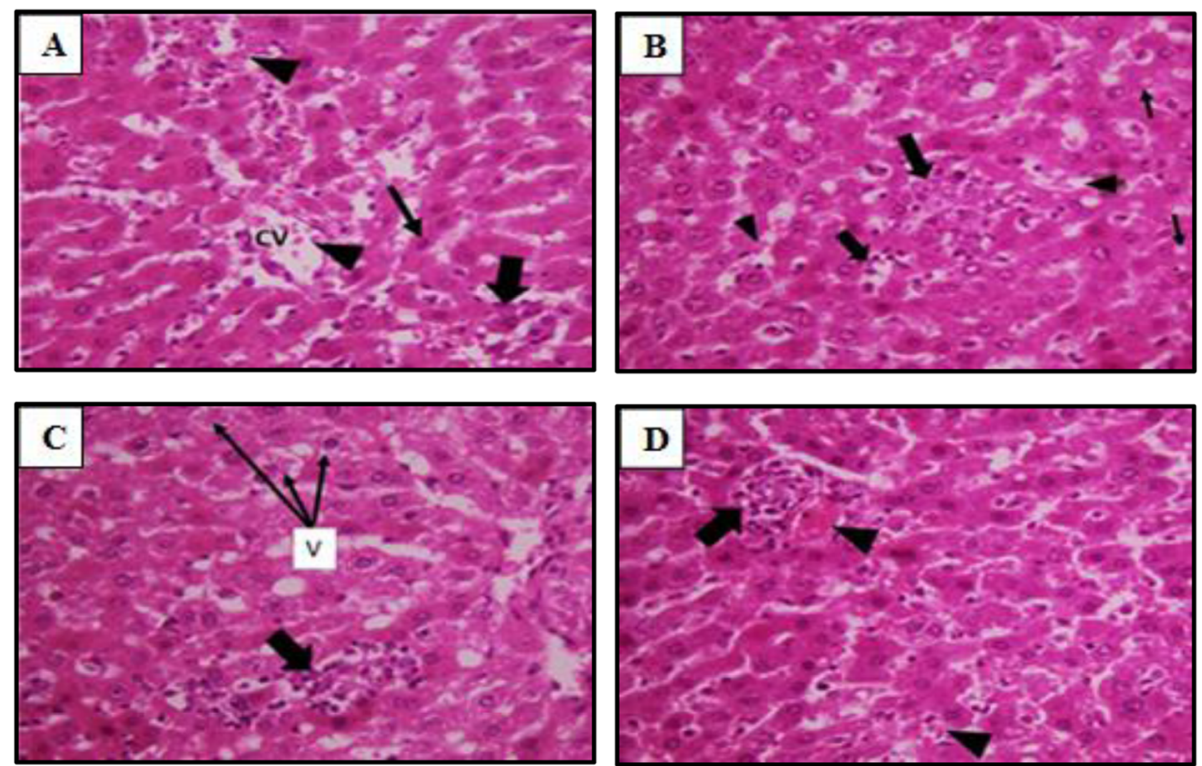

Fig. 5 Photomicrograph of liver tissue sections of $\mathbf{a}$ L-arginine-treated hepatic ischemia-reperfusion group, $\mathbf{b}$ exercise-trained hepatic ischemiareperfusion group, $\mathbf{c}$ oxytocin-treated hepatic ischemia-reperfusion group, and $\mathbf{d}$ exercise-trained and oxytocin-treated hepatic ischemiareperfusion group. (H\&E X400) 
Table 3 Liver histopathological scoring system showing number and frequency distribution (\%) of each component examined in two different field sections in 10 rats (20 fields/group)

\begin{tabular}{|c|c|c|c|c|c|c|c|c|c|c|c|c|c|c|c|}
\hline \multirow{2}{*}{$\begin{array}{l}\text { Component } \\
\text { Defined range Group }\end{array}$} & \multicolumn{5}{|c|}{ Congestion $^{\mathrm{a}}$} & \multicolumn{5}{|c|}{ Vacuolization $^{\mathrm{a}}$} & \multicolumn{5}{|c|}{ Necrosis } \\
\hline & $\overline{0}$ & 1 & 2 & 3 & $\overline{4}$ & $\overline{0}$ & 1 & 2 & 3 & $\overline{4}$ & 0 & 1 & 2 & 3 & $\overline{4}$ \\
\hline \multirow[t]{2}{*}{ Sham-operated control group } & 16 & 3 & 1 & 0 & 0 & 19 & 1 & 0 & 0 & 0 & 18 & 2 & 0 & 0 & $\overline{0}$ \\
\hline & $80 \%$ & $15 \%$ & $5 \%$ & & & $95 \%$ & $5 \%$ & & & & $90 \%$ & $10 \%$ & & & \\
\hline \multirow[t]{2}{*}{ Hepatic ischemia-reperfusion group } & 2 & 2 & 3 & 13 & 0 & 3 & 1 & 5 & 11 & 0 & 1 & 4 & 11 & 4 & 0 \\
\hline & $10 \%$ & $10 \%$ & $15 \%$ & $65 \%$ & & $15 \%$ & $5 \%$ & $25 \%$ & $55 \%$ & & $5 \%$ & $20 \%$ & $55 \%$ & $20 \%$ & \\
\hline \multirow[t]{2}{*}{ L-arginine-treated hepatic ischemia-reperfusion group } & 2 & 3 & 4 & 11 & 0 & 2 & 10 & 5 & 3 & 0 & 4 & 9 & 4 & 3 & 0 \\
\hline & $10 \%$ & $15 \%$ & $20 \%$ & $55 \%$ & & $10 \%$ & $50 \%$ & $25 \%$ & $15 \%$ & & $20 \%$ & $45 \%$ & $20 \%$ & $15 \%$ & \\
\hline \multirow[t]{2}{*}{ Exercise-trained hepatic ischemia-reperfusion group } & 3 & 12 & 3 & 2 & 0 & 4 & 12 & 3 & 1 & 0 & 6 & 10 & 2 & 2 & 0 \\
\hline & $15 \%$ & $60 \%$ & $15 \%$ & $10 \%$ & & $20 \%$ & $60 \%$ & $15 \%$ & $5 \%$ & & $30 \%$ & $50 \%$ & $10 \%$ & $10 \%$ & \\
\hline \multirow[t]{2}{*}{ Oxytocin-treated hepatic ischemia-reperfusion group } & 2 & 4 & 4 & 10 & 0 & 2 & 10 & 4 & 4 & 0 & 4 & 11 & 3 & 2 & 0 \\
\hline & $10 \%$ & $20 \%$ & $20 \%$ & $50 \%$ & & $10 \%$ & $50 \%$ & $20 \%$ & $20 \%$ & & $20 \%$ & $55 \%$ & $15 \%$ & $10 \%$ & \\
\hline \multirow[t]{2}{*}{ Exercise-trained and oxytocin-treated hepatic ischemia-reperfusion group } & 3 & 3 & 11 & 3 & 0 & 3 & 12 & 3 & 2 & 0 & 6 & 11 & 2 & 1 & 0 \\
\hline & $15 \%$ & $15 \%$ & $55 \%$ & $15 \%$ & & $15 \%$ & $60 \%$ & $15 \%$ & $10 \%$ & & $30 \%$ & $55 \%$ & $10 \%$ & $5 \%$ & \\
\hline
\end{tabular}

In component: necrosis, the defined ranges indicate; $0=$ No damage; $1=$ Single cell necrosis; $2=$ less than $30 \%$ necrosis; $3=$ less than $60 \%$ necrosis; $4=$ more than $60 \%$ necrosis

In components: Congestion and vacuolization, the defined ranges indicate; $0=$ No damage; $1=$ Minimal congestion, minimal vacuolization; $2=$ Mild congestion, mild vacuolization; $3=$ Moderate congestion, moderate vacuolization; $4=$ Severe congestion, severe vacuolization

The present hepatic functional and structural damage could be attributed to oxidative stress, increased ROS production, and lipid peroxidation associated with decreased antioxidant defense. This is proved by the increased plasma MDA and decreased plasma TAC. The decreased TAC could be explained by its over consumption to face the increased oxidative stress. Meanwhile, liver enzymes showed a significant positive correlation with MDA and a significant negative correlation with TAC.

This view is in line with previous reports which showed that reperfusion caused a generation of ROS that reacts with lipids in the cell membranes and initiate lipid peroxidation and is responsible for the IR injury [43, 44].

In addition, the initial stage of hepatic IR is reported to mediate the oxidative stress, the production of massive amounts of ROS, neutrophil activation, and its adherence to endothelial cells and release of proteases and finally induce death of hepatocyte [45].

In the current work, a significant positive correlation between the plasma levels of MDA and TNF- $\alpha$ is observed which could be explained by the ability of ROS to induce an inflammatory response via cellular signaling $[46,47]$. In addition to the significant increase in the plasma level of TNF- $\alpha$ following hepatic IR and its significant positive correlations with liver enzymes in this study, it denotes that TNF- $\alpha$ could be involved as an underlying mechanism in the current hepatic dysfunction and structural damage [48].

Other studies demonstrated that IR results in increased gene expression of both nuclear factor kappa B $(\mathrm{NF}-\mathrm{k} \beta$ ) and Toll-like receptor 4 (a protein involved in both innate and adaptive immune system response), which constantly increased TNF- $\alpha$ leading to liver damage $[38,49]$.

TNF- $\alpha$ has been reported to induce inflammation by several mechanisms. It interacts with other inflammatory cytokines and chemokines and activates the production of ROS [50]. In addition, TNF- $\alpha$ upregulates the expression of intercellular adhesion molecule- 1 and vascular cell adhesion molecule- 1 on endothelial cells, activating the transcription factor; NF- $k \beta$ resulting in the production of inflammatory mediators as TNF- $\alpha$, interleukins (IL); IL-1-B, IL-6, inducible nitric oxide synthase, and cyclo-oxygenase with amplification of the process of inflammation [51-53].

The decreased plasma level of nitrite observed in hepatic IR rats provides an additional explanation for the observed hepatic functional and structural damage. This deduced from significant increase in the serum levels of ALT and AST and their significant negative correlations with the plasma level of nitrite.

In line with this, Taha et al. [54] reported that IR injury is associated with a remarkable decrease in the bioavailability of NO, which represents an important initiating event in the pathophysiology of post-ischemic injury in a variety of different tissues, including the liver.

Diminished NO levels within liver during IR was found to be derived from both decreased production due to downregulation of endothelial nitric oxide synthase (eNOS) with hepatic IR, and increased scavenging by the elevated levels of ROS produced during reperfusion [1, $55,56]$. This scavenging causes the formation of peroxynitrite, the free radical, that rapidly reacts with all components such as proteins, lipids, and DNA further damaging the cell [57]. 
Insufficient $\mathrm{NO}$ production was assumed to be the main cause for vasoconstriction during reperfusion period, sinusoidal narrowing, and reduction of microcirculatory blood flow $[58,59]$. Moreover, hepatic IR injury was attributed to an imbalance in the ratio of endothelin (ET) to NO, with an increase in the plasma levels of ET and a concomitant fall in the plasma levels of NO in the first few hours of reperfusion [53].

The significant negative correlation exerted between the plasma nitrite and plasma MDA in the current work suggests that the oxidative stress could be implicated in reduction of nitrite plasma level.

Pretreatment with L-Arg attenuated hepatic IR injury as evidenced by decreased liver enzymes and hepatic damage. Hepatocytes had regression of necrosis, vacuolization, and nuclear pyknosis.

In this study, the favorable effects of L-Arg on hepatic functional and structural alterations could be attributed to the increased NO level deduced from the significant increase in the plasma level of nitrite by L-Arg treatment so that it reached the control values and the associated significant negative correlations existed between plasma level of nitrite and serum levels of ALT and AST.

This is in consistence with other studies, in which pretreatment with L-Arg resulted in activation of NO synthesis, increased concentrations of NO stable metabolites nitrite, and nitrate anions in both the blood and liver tissue and suppression of increased ALT and AST activities [60]. In addition, the activation of eNOS and the production of NO by this enzyme was found to increase liver graft preservation and improve liver function after reperfusion $[61,62]$.

The beneficial effects of the modulation of $\mathrm{L}-\mathrm{Arg} / \mathrm{NO}$ pathway was attributed before to the increase in NO bioavailability that acts by promoting microvasculature vasodilatation, opposing vasoconstriction mediated by ET, inhibition of platelet aggregation, and adhesion, as well as the reduction of interaction between leukocytes and endothelial surface resulting in the reduction of the inflammatory activity, and inhibiting caspases to prevent apoptosis, in addition to the superoxide scavenging property and detoxification of ROS following L-Arg use $[63,64]$.

It seems that L-Arg mediates its protective effect in hepatic IR in the present study not only through NO, but also has direct antioxidant effect deduced from the significant decrease in the plasma level of MDA and the significant increase in the plasma level of TAC. This assumption is supported by the significant negative correlations existed between nitrite and MDA, as well as the significant positive correlation between nitrite and TAC. In line with our assumption, in a rat model of carbon tetrachloride-induced hepatotoxicity, pre- and posttreatment with L-Arg decreased the hepatic MDA content and enhanced the hepatic antioxidant enzymes; these results were attributed either to $\mathrm{NO}$ ability to function as scavenger or to the antioxidant effects of LArg itself [65].

The other protective mechanisms of L-Arg could be attributed to its anti-inflammatory mechanism. This is deduced from the suppression of TNF- $\alpha$ plasma level by treatment as well as the significant negative correlation between plasma levels of nitrite and TNF- $\alpha$.

In agreement, NO was reported to inhibit proinflammatory cytokines, including TNF- $\alpha$, IL-1B, IL- $1 \alpha$, and IL-12, which may induce inflammatory cascade during liver IR injury $[8,54]$.

The exercise model encountered in this study was in the form of chronic moderate swimming exercise, $2 \mathrm{~h}$ daily and 6 days/week for 4 weeks. This exercise training ameliorated hepatic injury and dysfunction induced by hepatic IR, as revealed by a significant decrease in the serum levels of ALT and AST and the plasma levels of MDA and TNF- $\alpha$, but a significant increase in TAC and nitrite levels. Also, an improvement of hepatic morphology was demonstrated by the decreased score of necrosis, vacuolization, and congestion compared to hepatic IR group.

These findings denote that exercise training abrogated hepatic functional and structural impairment induced by hepatic IR. These results are consistent with previous studies [21, 66, 67].

Exercise training exerts more powerful antiinflammatory and antioxidant defense effects than L-Arg with less hepatocellular injury. This is evidenced by significant decrease in plasma TNF- $\alpha$ and the increase in plasma TAC that reached control values and better regression of scores of vascular congestion, hepatocyte necrosis, and vacuolization. Meanwhile, the serum levels of ALT and AST and plasma levels of nitrite and MDA were insignificantly changed.

The current proposed anti-inflammatory role of exercise training is supported by other studies [66, 68-70]. Similarly, Dallak et al. [71] showed that swim exercise for $60 \mathrm{~min}$ three times per week, for 4 weeks, reduced the serum levels of inflammatory biomarker, TNF- $\alpha$ in a rat model of high fat diet, via reduction in visceral fat mass with a subsequent decrease in adipokine release.

The decrease in final body weight and BW \% change recorded in the Ex + IR group (unpublished data) compared to the IR, L-Arg + IR, and sham groups could provide possible explanation for the reduction of plasma TNF- $\alpha$. The adipose tissue was found to be able to produce inflammatory cytokines such as TNF- $\alpha$ and IL-6 and several potent chemo-attractant cytokines [72]. The accumulation of monocytes as macrophages in the adipose tissue is thought to be a major source of increased systemic concentrations of inflammatory cytokines [73]. 
Opposite to our work, the intense exercise was found to induce muscle microtraumas, increase the release of inflammatory cytokines into the bloodstream [74, 75], and lead to tissue damage with increased production of ROS and inflammatory mediators [76, 77] induce hepatic inflammation through inflammatory cell infiltration in rats [78]. This contradiction could result from the use of different intensities and durations of exercise models other than the model used in the current study.

Exercise training in the present work had protective effect not only through anti-inflammatory mechanisms but also had antioxidant effect. Other studies showed that regular exercise enhance hepatic antioxidant capacity, redox status, reduced the hepatic MDA level which reflect lipid peroxidation $[66,67,79,80]$.

On the contrary to the present results, severe exercise was found to mediate an oxidative effect and to increase the hepatic MDA levels. The authors assumed that intense exercise increases oxygen consumption and may produce an imbalance between ROS and antioxidants, inducing oxidative stress [76].

Compared to L-Arg treatment, moderate intensity exercise did not differ significantly as regards the serum levels of ALT and AST and the plasma levels of MDA and TAC but showed only a significant decrease in the plasma levels of TNF- $\alpha$ and nitrite which indicated that the hepatoprotective effect of moderate intensity exercise was largely dependent of its anti-inflammatory effects and only dependent partly on increasing NO.

Compared to hepatic IR, Oxy pretreatment in the Oxy + IR group resulted in improvement of hepatic dysfunction which was observed from the significant reduction in the serum levels of ALT and AST, plasma levels of MDA and TNF- $\alpha$ together with significant increase in TAC and nitrite and alleviated IR histopathological injury. However, such improvements did not reach the control levels. These results are in agreement of other studies [81-83].

The beneficial effect of Oxy against hepatic IR could be attributed to suppression of oxidative stress as confirmed by the significant decrease in plasma level MDA and the significant increase in the plasma level of TAC. In addition to its anti-inflammatory effect as seen by decrease in plasma TNF- $\alpha$.

The antioxidative effect of Oxy was attributed to its ability to break lipid peroxidation chain $[82,84,85]$. While its anti-inflammatory effect was mediated by reduction of the serum TNF- $\alpha$, inhibition of neutrophils migration and neutrophil-derived pro-inflammatory cytokines, parenchymal injury, and tissue inflammation [81].

Also, the increased plasma level of nitrite upon Oxy treatment in the Oxy + IR group compared to the hepatic IR group, could be a third mechanism by which Oxy can produce hepatoprotection during IR.
However, the Oxy + IR group did not differ from the L-Arg + IR group regarding the serum levels of ALT and AST and the plasma levels of MDA and TAC but only showed a significant reduction in the plasma levels of TNF- $\alpha$ and nitrite which indicated that hepatoprotective effect Oxy was mediated mainly through its antiinflammatory effect of but less on its NO producing effect.

Combination of both exercise training and Oxy pretreatment in the Ex + Oxy + IR group resulted in the attenuation of the hepatic damage caused by hepatic IR evidenced by the significant decrease in serum levels of ALT and AST, and plasma levels of MDA and TNF- $\alpha$ together with a significant elevation in the plasma levels of TAC and nitrite and histopathological improvement.

On comparison with L-Arg, combination of both exercise and Oxy in this study displayed more pronounced hepatoprotection evidenced by the significant decrease in the serum levels of ALT and AST together with recession of histopathological injury, to a greater extent than in L-Arg. Such superiority of combined treatment over L-Arg could be attributed to their more prominent antioxidant and anti-inflammatory effects but not due to their NO-enhancing effect as the plasma levels of MDA, TNF- $\alpha$, and nitrite were significantly lower than in LArg-treated group.

Compared to exercise only group (Ex + IR), the combination of exercise and Oxy in the Ex + Oxy + IR group exerted additive effects which offered more hepatoprotection where the levels of ALT, AST, TNF- $\alpha$, and MDA were significantly lowered indicating dampening of the inflammatory response and lipid peroxidation which is independent on $\mathrm{NO}$ as its level did not differ significantly in both groups.

\section{Conclusion}

Hepatic IR impaired functional and structural integrity of the liver. Pretreatment with L-Arg, Oxy, and exercise training abrogated hepatic functional and structural impairment induced by IR. Exercise training exerts more powerful anti-inflammatory and antioxidant defense effects than L-Arg, whereas Oxy acts as more powerful anti-inflammatory agent, however, a less powerful NOinducing agent than L-Arg. Combination of both exercise and Oxy displayed more pronounced hepatoprotection on comparison with L-Arg on hepatic structural and functional changes induced by hepatic IR and such superiority of combined treatment over L-Arg could be attributed to their more prominent antioxidant and antiinflammatory effects but not due to their NO-enhancing effect.

\section{Abbreviations}

ALT: Alanine transferase; ANOVA: Analysis of variance; AST: Aspartate transferase; ELISA: Enzyme immunoassay; ET: Endothelin; eNOS: Endothelial 
nitric oxide synthase; Ex + IR group: Exercise-trained hepatic ischemiareperfusion group; Ex + Oxy + IR group: Exercise-trained and oxytocintreated hepatic ischemia-reperfusion group; H\&E: Hematoxylin and eosin; IL: Interleukin; IR group: Hepatic ischemia-reperfusion group; IR: Ischemia reperfusion; KCs: Kupffer cells; L-Arg + IR group: L-arginine-treated hepatic ischemia-reperfusion group; L-Arg: L-arginine; LSD: Least significant difference; MASRI: The Faculty of Medicine, Ain Shams University Research Institute; MDA: Malondialdehyde; NF-kß: Nuclear factor kappa B; NO: Nitric oxide; NOS: Nitric oxide synthase; Oxy + IR group: Oxytocin-treated hepatic ischemia-reperfusion group; Oxy: Oxytocin; ROS: Reactive oxygen species; Sham group: Sham-operated control; TAC: Total antioxidant capacity; TNFa: Tumor necrosis factor-a

\section{Acknowledgements}

I would like to thank Dr. Laila Ahmed Rashed, Professor of Medical Biochemistry and Molecular Biology, Faculty of Medicine, Cairo University, for her contribution in the biochemical studies.

\section{Authors' contributions}

AE was responsible for the manuscript elaboration and for conducting the project and worked on all of its stages. DA.S. and DA assisted in animal handling and in the discussions regarding the results. WB assisted in the histological procedures and result interpretation. BE revised the manuscript. MA is the main investigator who planned, designed, and supervised the project. The authors approved the final manuscript.

\section{Funding}

Not applicable.

\section{Availability of data and materials}

The data used and/or analyzed during the current study are available from the corresponding author on a reasonable request.

\section{Declarations}

\section{Ethics approval and consent to participate}

The study protocol was approved by the Research Ethical Committee of Faculty of Medicine, Ain Shams University (FMASU, MD 100/2018).

\section{Consent for publication}

Not applicable.

\section{Competing interests}

The authors declare that they have no competing interests.

\section{Author details}

${ }^{1}$ Physiology Department, Faculty of Medicine, Ain Shams University, Cairo, Egypt. ${ }^{2}$ Histology Department, Faculty of Medicine, Ain Shams University, Cairo, Egypt.

\section{Received: 29 December 2020 Accepted: 18 May 2021}

Published online: 31 May 2021

\section{References}

1. Peralta C, Jiménez-Castro MB, Gracia-Sancho J (2013) Hepatic ischemia and reperfusion injury: effects on the liver sinusoidal milieu. J Hepatol. 59(5): 1094-1106. https://doi.org/10.1016/j.jhep.2013.06.017

2. Costa CCC, Pereira NG, Machado ALM, Dórea MA, Cruz RMMD, Silva RC, Domingues RJS, Yasojima EY (2019) Splenic ischemic preconditioning attenuates oxidative stress induced by hepatic ischemia-reperfusion in rats. Acta Cir Bras. 34(7):e201900707. https://doi.org/10.1590/s0102-8650201 90070000007

3. Jaeschke $H$ (2003) Molecular mechanisms of hepatic ischemia-reperfusion injury and preconditioning. Am J Physiol Gastrointest Liver Physiol. 284(1): G15-G26. https://doi.org/10.1152/ajpgi.00342.2002

4. Douzinas EE, Livaditi O, Tasoulis MK, Prigouris P, Bakos D, Goutas N, Vlachodimitropoulos D, Andrianakis I, Betrosian A, Tsoukalas GD (2012) Nitrosative and oxidative stresses contribute to post-ischemic liver injury following severe hemorrhagic shock: the role of hypoxemic resuscitation. PLoS One. 7(3):e32968. https://doi.org/10.1371/journal.pone.0032968
5. van Riel WG, van Golen RF, Reiniers MJ, Heger M, van Gulik TM (2016) How much ischemia can the liver tolerate during resection? Hepatobiliary Surg Nutr. 5(1):58-71. https://doi.org/10.3978/j.issn.2304-3881.2015.07.05

6. Wang W, Wu L, Li J, Ji J, Chen K, Yu Q, Li S, Feng J, Liu T, Zhang J, Chen J, Zhou Y, Mao Y, Wang F, Dai W, Fan X, Guo C, Wu J (2019) Alleviation of hepatic ischemia reperfusion injury by oleanolic acid pretreating via reducing $\mathrm{HMGB1}$ release and inhibiting apoptosis and autophagy. Mediators Inflamm. 2019:3240713-3240710. https://doi.org/10.1155/201 9/3240713

7. Montalvo-Jave EE, Escalante-Tattersfield T, Ortega-Salgado JA, Piña E, Geller DA (2008) Factors in the pathophysiology of the liver ischemia-reperfusion injury. J Surg Res. 147(1):153-159. https://doi.org/10.1016/j.jss.2007.06.015

8. Guan LY, Fu PY, Li PD, Li ZN, Liu HY, Xin MG, Li W (2014) Mechanisms of hepatic ischemia-reperfusion injury and protective effects of nitric oxide. World J Gastrointest Surg. 6(7):122-128. https://doi.org/10.4240/wjgs.v6. i7.122

9. Jiang WW, Kong LB, Li GQ, Wang XH (2009) Expression of iNOS in early injury in a rat model of small-for-size liver transplantation. Hepatobiliary Pancreat Dis Int. 8(2):146-151. 19357027

10. Lucas ML, Rhoden CR, Rhoden EL, Zettler CG, Mattos AA (2015) Effects of Larginine and L-NAME on ischemia-reperfusion in rat liver. Acta Cir Bras. 30(5):345-352. https://doi.org/10.1590/S0102-865020150050000006

11. Seo DY, Lee SR, Kim N, Ko KS, Rhee BD, Han J (2014) Humanized animal exercise model for clinical implication. Pflugers Arch. 466(9):1673-1687. https://doi.org/10.1007/s00424-014-1496-0

12. Orci LA, Gariani K, Oldani G, Delaune V, Morel P, Toso C (2016) Exercisebased interventions for nonalcoholic fatty liver disease: a meta-analysis and meta-regression. Clin Gastroenterol Hepatol. 14(10):1398-1411. https://doi. org/10.1016/j.cgh.2016.04.036

13. Jakicic JM, Rogers RJ, Davis KK, Collins KA (2018) Role of physical activity and exercise in treating patients with overweight and obesity. Clin Chem. 64(1):99-107. https://doi.org/10.1373/clinchem.2017.272443

14. Mastorakos G, Pavlatou M (2005) Exercise as a stress model and the interplay between the hypothalamus-pituitary-adrenal and the hypothalamus-pituitary-thyroid axes. Horm Metab Res. 37(9):577-584. https://doi.org/10.1055/s-2005-870426

15. Pillon Barcelos R, Bresciani G, Rodriguez-Miguelez P, Cuevas MJ, Soares FA, Barbosa NV, González-Gallego J (2016) Diclofenac pretreatment effects on the toll-like receptor 4/nuclear factor kappa B-mediated inflammatory response to eccentric exercise in rat liver. Life Sci. 148:247-253. https://doi. org/10.1016/j.lfs.2016.02.006

16. Pillon Barcelos R, Freire Royes LF, Gonzalez-Gallego J, Bresciani G (2017) Oxidative stress and inflammation: liver responses and adaptations to acute and regular exercise. Free Radic Res. 51(2):222-236. https://doi.org/10.1080/1 0715762.2017 .1291942

17. Viero C, Shibuya I, Kitamura N, Verkhratsky A, Fujihara H, Katoh A, Ueta Y, Zingg HH, Chvatal A, Sykova E, Dayanithi G (2010) REVIEW: Oxytocin: crossing the bridge between basic science and pharmacotherapy. CNS Neurosci Ther. 16(5):e138-e156. https://doi.org/10.1111/j.1755-5949.2010.001 85.x

18. Ondrejcakova M, Bakos J, Garafova A, Kovacs L, Kvetnansky R, Jezova D (2010) Neuroendocrine and cardiovascular parameters during simulation of stress-induced rise in circulating oxytocin in the rat. Stress. 13(4):314-322. https://doi.org/10.3109/10253891003596822

19. Uvnäs Moberg K, Handlin L, Kendall-Tackett K, Petersson M (2019) Oxytocin is a principal hormone that exerts part of its effects by active fragments. Med Hypotheses. 133:109394. https://doi.org/10.1016/j.mehy.2019.109394

20. Tas Hekimoglu A, Toprak G, Akkoc H, Evliyaoglu O, Ozekinci S, Kelle I (2013) Oxytocin ameliorates remote liver injury induced by renal ischemiareperfusion in rats. Korean J Physiol Pharmacol. 17(2):169-173. https://doi. org/10.4196/kjpp.2013.17.2.169

21. Shibamoto T, Kuda Y, Tanida M, Wang M, Kurata Y (2015) Exercise attenuates ischemia-reperfusion injury of nonalcoholic fatty liver in OLETF rat. Gastroenterol Pancreatol Liver Disord. 2(2):1-6. https://doi.org/10.1522 6/2374-815X/2/2/00132

22. Chattopadhyay P, Verma N, Verma A, Kamboj T, Khan NA, Wahi AK (2008) Larginine protects from pringle manoeuvere of ischemia-reperfusion induced liver injury. Biol Pharm Bull. 31(5):890-892. https://doi.org/10.1248/bpb.31. 890

23. Abd-Allah AB, Megahed AAY, Gomaa RS, Hussein SFE (2013) Effect of moderate intensity exercise on serum visfatin level in male rat model of 
obesity. AAMJ. 10(4):20-42 http://www.aamj.eg.net/inner/jarticle.aspx?aid= 2045

24. Mostafa D, Khaleel E, Ahmed G (2015) Mechanism of action of oxytocin as cardioprotection in rat model of myocardial infarction. IOSR J Dent Med Sci. 14:25-36 https://www.iosrjournals.org/iosr-jdms/papers/Vol14-issue10/ Version-1/E0141012536.pdf

25. Manna I, Jana K, Samanta PK (2004) Effect of different intensities of swimming exercise on testicular oxidative stress and reproductive dysfunction in mature male albino Wistar rats. Indian J Exp Biol. 42(8):816822 PMID: 15573534

26. Ara C, Kirimlioglu H, Karabulut AB, Coban S, Ay S, Harputluoglu M, Kirimlioglu V, Yilmaz S (2005) Protective effect of resveratrol against oxidative stress in cholestasis. J Surg Res. 127(2):112-117. https://doi.org/1 0.1016/j.jss.2005.01.024

27. Barnes CD, Etherington LG (1964) Drug dosage in laboratory animals, a handbook. Berkeley (\& Los Angeles): Univ. Calif. Press. Cambridge Univ. Press, London, p 41 (302)

28. Henry RJ (1964) Clinical chemistry, principles and techniques, vol 1964. New York: Hoeber Medical, Harper-Row; 2021. p 190

29. Tietz NW (1976) Fundamentals of clinical chemistry. W.B. Saunders Co., Philadelphia

30. Provisional recommendations on IFCC methods for the measurement of catalytic concentrations of enzymes Part 2 (1977) IFCC method for aspartate aminotransferase. J Clin Chem Clin Biochem. 15(1):39-51 PMID: 190335

31. Montgomery HAC, Dymock JF (1961) the determination of nitrite in water. Analyst. 86:414-416

32. Satoh K (1978) Serum lipid peroxide in cerebrovascular disorders determined by a new colorimetric method. Clin Chim Acta. 90(1):37-43. https://doi.org/10.1016/0009-8981(78)90081-5

33. Ohkawa H, Ohishi N, Yagi K (1979) Assay for lipid peroxides in animal tissues by thiobarbituric acid reaction. Anal Biochem. 95(2):351-358. https://doi. org/10.1016/0003-2697(79)90738-3

34. Koracevic D, Koracevic G, Djordjevic V, Andrejevic S, Cosic V (2001) Method for the measurement of antioxidant activity in human fluids. J Clin Pathol. 54(5):356-361. https://doi.org/10.1136/jcp.54.5.356

35. Bancroft JD, Gamble M (2008) Theory and practice of histological techniques, 6th edn. Elsevier, Churchill Livingstone China

36. Suzuki S, Toledo-Pereyra LH, Rodriguez FJ, Cejalvo D (1993) Neutrophil infiltration as an important factor in liver ischemia and reperfusion injury Modulating effects of FK506 and cyclosporine. Transplantation. 55(6):12651272. https://doi.org/10.1097/00007890-199306000-00011

37. Mard SA, Akbari G, Dianat M, Mansouri E (2017) Protective effects of crocin and zinc sulfate on hepatic ischemia-reperfusion injury in rats: a comparative experimental model study. Biomed Pharmacother. 96:48-55. https://doi.org/10.1016/j.biopha.2017.09.123

38. Kamel EO, Hassanein EHM, Ahmed MA, Ali FEM (2020) Perindopril ameliorates hepatic ischemia reperfusion injury via regulation of NF-KB-p65/ TLR-4, JAK1/STAT-3, Nrf-2, and PI3K/Akt/mTOR signaling pathways. Anat Rec (Hoboken). 303(7):1935-1949. https://doi.org/10.1002/ar.24292

39. Xia H, Liu Z, Liang W, Zeng X, Yang Y, Chen P, Zhong Z, Ye Q (2020) Vagus nerve stimulation alleviates hepatic ischemia and reperfusion injury by regulating glutathione production and transformation. Oxid Med Cell Longev. 2020:1079129-1079115. https://doi.org/10.1155/2020/1079129

40. Peralta C, Fernández L, Panés J, Prats N, Sans M, Piqué JM, Gelpí E, RosellóCatafau J (2001) Preconditioning protects against systemic disorders associated with hepatic ischemia-reperfusion through blockade of tumor necrosis factor-induced P-selectin up-regulation in the rat. Hepatology. 33(1):100-113. https://doi.org/10.1053/jhep.2001.20529

41. Serracino-Inglott F, Virlos IT, Habib NA, Williamson RC, Mathie RT (2002) Adenosine preconditioning attenuates hepatic reperfusion injury in the rat by preventing the down-regulation of endothelial nitric oxide synthase. BMC Gastroenterol. 2(1):22. https://doi.org/10.1186/1471-230x-2-22

42. Crockett ET, Galligan JJ, Uhal BD, Harkema J, Roth R, Pandya K (2006) Protection of early phase hepatic ischemia-reperfusion injury by cholinergic agonists. BMC Clin Pathol. 6(1):3. https://doi.org/10.1186/1472-6890-6-3

43. Vardanian AJ, Busuttil RW, Kupiec-Weglinski JW (2008) Molecular mediators of liver ischemia and reperfusion injury: a brief review. Mol Med. 14(5-6): 337-345. https://doi.org/10.2119/2007-00134

44. Abu-Amara M, Yang SY, Tapuria N, Fuller B, Davidson B, Seifalian A (2010) Liver ischemia/reperfusion injury: processes in inflammatory networks--a review. Liver Transpl. 16(9):1016-1032. https://doi.org/10.1002/t.22117
45. Nastos C, Kalimeris K, Papoutsidakis N, Tasoulis MK, Lykoudis PM, Theodoraki K, Nastou D, Smyrniotis V, Arkadopoulos N (2014) Global consequences of liver ischemia/reperfusion injury. Oxid Med Cell Longev. 2014:906965906913. https://doi.org/10.1155/2014/906965

46. Espinosa-Diez C, Miguel V, Mennerich D, Kietzmann T, Sánchez-Pérez P, Cadenas S, Lamas S (2015) Antioxidant responses and cellular adjustments to oxidative stress. Redox Biol. 6:183-197. https://doi.org/10.1016/j.redox.201 5.07 .008

47. Granger DN, Kvietys PR (2015) Reperfusion injury and reactive oxygen species: the evolution of a concept. Redox Biol. 6:524-551. https://doi.org/1 0.1016/j.redox.2015.08.020

48. Siriussawakul A, Zaky A, Lang JD (2010) Role of nitric oxide in hepatic ischemia-reperfusion injury. World I Gastroenterol. 16(48):6079-6086. https:// doi.org/10.3748/wjg.v16.148.6079

49. Mahmoud MF, Gamal S, El-Fayoumi HM (2014) Limonin attenuates hepatocellular injury following liver ischemia and reperfusion in rats via tolllike receptor dependent pathway. Eur J Pharmacol. 740:676-6782. https:// doi.org/10.1016/j.ejphar.2014.06.010

50. Koh WU, Kim J, Lee J, Song GW, Hwang GS, Tak E, Song JG (2019) Remote ischemic preconditioning and diazoxide protect from hepatic ischemic reperfusion injury by inhibiting HMGB1-induced TLR4/MyD88/NF-KB signaling. Int J Mol Sci. 20(23):5899. https://doi.org/10.3390/ijms20235899

51. Moniruzzaman M, Ghosal I, Das D, Chakraborty SB (2018) Melatonin ameliorates $\mathrm{H}_{2} \mathrm{O}_{2}$-induced oxidative stress through modulation of Erk/Akt/ NFkB pathway. Biol Res. 51(1):17. https://doi.org/10.1186/s40659-018-0168-5

52. Tang F, Wang Y, Hemmings BA, Rüegg C, Xue G (2018) PKB/Akt-dependent regulation of inflammation in cancer. Semin Cancer Biol. 48:62-69. https:// doi.org/10.1016/j.semcancer.2017.04.018

53. Rampes S, Ma D (2019) Hepatic ischemia-reperfusion injury in liver transplant setting: mechanisms and protective strategies. J Biomed Res. 33(4):221-234. https://doi.org/10.7555/JBR.32.20180087

54. Taha MO, Caricati-Neto A, Ferreira RM, Simões Mde J, Monteiro HP, Fagundes DJ (2012) L-arginine in the ischemic phase protects against liver ischemia-reperfusion injury. Acta Cir Bras 27(9):616-623. https://doi.org/10.1 590/s0102-86502012000900005

55. Tarsi AK, Ansari M, Ghazi-Khansari M, Keramatipour M, Ebrahimi A, Emamgholipour S, Joybari SV (2012) Melatonin inhibits endothelin-1 and induces endothelial nitric oxide synthase genes expression throughout hepatic ischemia/reperfusion in rats. Afr J Biotechnol. 11(58):12222-12228. https://doi.org/10.5897/AJB12.1577

56. Ghanaat K, Valizadeh-Dizajeykan A, Malekzadeh-Shafaroudi M, KhonakdarTarsi A (2016) Effect of dexamethasone on the endothelin-1 (ET-1) and endothelial nitric oxide synthase (eNOS) genes expression during hepatic warm ischemia/reperfusion in rat. Res Mol Med (RMM) 4(4):8-14 URL: http:// rmm.mazums.ac.ir/article-1-216-en.htm

57. Hide D, Ortega-Ribera M, Garcia-Pagan JC, Peralta C, Bosch J, Gracia-Sancho $J$ (2016) Effects of warm ischemia and reperfusion on the liver microcirculatory phenotype of rats: underlying mechanisms and pharmacological therapy. Sci Rep. 6(1):22107. https://doi.org/10.1038/ srep22107

58. Klune JR, Tsung A (2010) Molecular biology of liver ischemia/reperfusion injury: established mechanisms and recent advancements. Surg Clin North Am. 90(4):665-677. https://doi.org/10.1016/j.suc.2010.04.003

59. Bektas S, Karakaya K, Can M, Bahadir B, Guven B, Erdogan N, Ozdamar SO (2016) The effects of tadalafil and pentoxifylline on apoptosis and nitric oxide synthase in liver ischemia/reperfusion injury. Kaohsiung J Med Sci. 32(7):339-347. https://doi.org/10.1016/j.kjms.2016.05.005

60. Oleshchuk OM, Posokhova KA, Мудра AY (2014) L-arginine, but not L-name protects against liver injury induced by experimental ischemia-reperfusion. Int J Med Med Res 1(1). https://doi.org/10.11603/ijmmr.2413-6077.2015.1.2820

61. Zaouali MA, Ben Abdennebi H, Padrissa-Altés S, Alfany-Fernandez I, Rimola A, Roselló-Catafau J (2011) How Institut Georges Lopez preservation solution protects nonsteatotic and steatotic livers against ischemiareperfusion injury. Transplant Proc. 43(1):77-79. https://doi.org/10.1016/j.tra nsproceed.2010.12.026

62. Tabka D, Bejaoui M, Javellaud J, Roselló-Catafau J, Achard JM, Abdennebi HB (2015) Effects of Institut Georges Lopez-1 and Celsior preservation solutions on liver graft injury. World J Gastroenterol. 21(14):4159-4168. https://doi. org/10.3748/wjg.v21.i14.4159

63. Katsumi H, Nishikawa M, Yamashita F, Hashida M (2008) Prevention of hepatic ischemia/reperfusion injury by prolonged delivery of nitric oxide to 
the circulating blood in mice. Transplantation. 85(2):264-269. https://doi. org/10.1097/TP.0b013e31815e902b

64. Abu-Amara M, Yang SY, Seifalian A, Davidson B, Fuller B (2012) The nitric oxide pathway--evidence and mechanisms for protection against liver ischaemia reperfusion injury. Liver Int. 32(4):531-543. https://doi.org/1 0.1111/j.1478-3231.2012.02755.x

65. Al-Dalaen S, Alzyoud J, Al-Qtaitat A (2016) The effects of L-arginine in modulating liver antioxidant biomarkers within carbon tetrachloride induced hepatotoxicity: experimental study in rats. Biomed Pharmacol $\rfloor$ 9(1):293-298. https://doi.org/10.13005/bpj/938

66. El-Saka M, Madi N, Abou Fard G (2014) Effect of moderate and severe swimming exercise on hepatic injury and apoptosis induced by renal ischemia reperfusion in male albino rats. Bull Egypt Soc Physiol Sci 34(2): 160-175. https://doi.org/10.21608/besps.2014.34789

67. Silva RN, Bueno PG, Avó LR, Nonaka KO, Selistre-Araújo HS, Leal AM (2014) Effect of physical training on liver expression of activin A and follistatin in a nonalcoholic fatty liver disease model in rats. Braz J Med Biol Res. 47(9):746752. https://doi.org/10.1590/1414-431×20143869

68. Huang CC, Chiang WD, Huang WC, Huang CY, Hsu MC, Lin WT (2013) Hepatoprotective effects of swimming exercise against d-galactose-induced senescence rat model. Evid Based Complement Alternat Med. 2013:275431275439. https://doi.org/10.1155/2013/275431

69. Rodriguez-Miguelez P, Fernandez-Gonzalo R, Almar M, Mejías Y, Rivas A, de Paz JA, Cuevas MJ, González-Gallego J (2014) Role of Toll-like receptor 2 and 4 signaling pathways on the inflammatory response to resistance training in elderly subjects. Age (Dordr). 36(6):9734. https://doi.org/10.1007/s1 1357-0149734-0

70. Gjevestad GO, Holven KB, Ulven SM (2015) Effects of exercise on gene expression of inflammatory markers in human peripheral blood cells: a systematic review. Curr Cardiovasc Risk Rep. 9(7):34. https://doi.org/10.1007/ s12170-015-0463-4

71. Dallak MA, Bin-Jaliah I, Albawardi A, Haidara MA, Sakr HF, Eid RA, Hassan WN, Al-Ani B (2018) Swim exercise training ameliorates hepatocyte ultrastructural alterations in rats fed on a high fat and sugar diet. Ultrastruct Pathol. 42(2):155-161. https://doi.org/10.1080/01913123.2017.1422581

72. Shanely RA, Nieman DC, Henson DA, Jin F, Knab AM, Sha W (2013) Inflammation and oxidative stress are lower in physically fit and active adults. Scand J Med Sci Sports. 23(2):215-223. https://doi.org/10.1111/j.16000838.2011.01373.x

73. Gleeson M, Bishop NC, Stensel DJ, Lindley MR, Mastana SS, Nimmo MA (2011) The anti-inflammatory effects of exercise: mechanisms and implications for the prevention and treatment of disease. Nat Rev Immunol. 11(9):607-615. https://doi.org/10.1038/nri3041

74. Liburt NR, Adams AA, Betancourt A, Horohov DW, McKeever KH (2010) Exercise-induced increases in inflammatory cytokines in muscle and blood of horses. Equine Vet J Suppl (38):280-288. https://doi.org/10.1111/j.2042-33 06.2010.00275.x

75. Bernecker C, Scherr J, Schinner S, Braun S, Scherbaum WA, Halle M (2013) Evidence for an exercise induced increase of TNF- $a$ and IL-6 in marathon runners. Scand J Med Sci Sports. 23(2):207-214. https://doi.org/10.1111/j.1 600-0838.2011.01372.x

76. Xu J, Li Y (2012) Effects of salidroside on exhaustive exercise-induced oxidative stress in rats. Mol Med Rep. 6(5):1195-1198. https://doi.org/10.3 892/mmr.2012.1060

77. Korivi M, Chen CT, Yu SH, Ye W, Cheng IS, Chang JS, Kuo CH, Hou CW (2019) Seaweed supplementation enhances maximal muscular strength and attenuates resistance exercise-induced oxidative stress in rats. Evid Based Complement Alternat Med. 2019:3528932-3528939. https://doi.org/10.11 55/2019/3528932

78. Praphatsorn P, Thong-Ngam D, Kulaputana O, Klaikeaw N (2010) Effects of intense exercise on biochemical and histological changes in rat liver and pancreas. Asian Biomed. 4(4):619-625. https://doi.org/10.2478/abm-20100078

79. Hoene M, Weigert C (2010) The stress response of the liver to physical exercise. Exerc Immunol Rev. 16:163-183 PMID: 20839498. http://eir-isei.de/2 010/eir-2010-163-article.pdf

80. Lima FD, Stamm DN, Della-Pace ID, Dobrachinski F, de Carvalho NR, Royes LF, Soares FA, Rocha JB, González-Gallego J, Bresciani G (2013) Swimming training induces liver mitochondrial adaptations to oxidative stress in rats submitted to repeated exhaustive swimming bouts. PLoS One. 8(2):e55668. https://doi.org/10.1371/journal.pone.0055668
81. Düşünceli F, Işeri SO, Ercan F, Gedik N, Yeğen C, Yeğen BC (2008) Oxytocin alleviates hepatic ischemia-reperfusion injury in rats. Peptides. 29(7):12161222. https://doi.org/10.1016/j.peptides.2008.02.010

82. Welch MG, Anwar M, Chang CY, Gross KJ, Ruggiero DA, Tamir H, Gershon MD (2010) Combined administration of secretin and oxytocin inhibits chronic colitis and associated activation of forebrain neurons. Neurogastroenterol Motil. 22(6):654-e202. https://doi.org/10.1111/j.1365-2 982.2010.01477.x

83. Saad AH, Nazmy WH, Ibrahim HM, Hussien A (2013) Oxytocin induced protection against non-alcoholic fatty liver disease in rats. Minia J Med Res (MJMR). 24(2):33-40 https://www.minia.edu.eg/med/Files/june2013pdf/6.\%2 01219.pdf

84. Ișeri SO, Sener G, Sağlam B, Gedik N, Ercan F, Yeğen BC (2005) Oxytocin ameliorates oxidative colonic inflammation by a neutrophil-dependent mechanism. Peptides. 26(3):483-491. https://doi.org/10.1016/j.peptides.2 004.10 .005

85. Elberry AA, Refaie SM, Kamel M, Ali T, Darwish H, Ashour O (2013) Oxytocin ameliorates cisplatin-induced nephrotoxicity in Wistar rats. Ann Saudi Med 33(1):57-62. https://doi.org/10.5144/0256-4947.2013.57

\section{Publisher's Note}

Springer Nature remains neutral with regard to jurisdictional claims in published maps and institutional affiliations.

\section{Submit your manuscript to a SpringerOpen ${ }^{\circ}$ journal and benefit from:}

- Convenient online submission

- Rigorous peer review

- Open access: articles freely available online

- High visibility within the field

- Retaining the copyright to your article

Submit your next manuscript at $\boldsymbol{\nabla}$ springeropen.com 